\title{
Unplanned Substance Use Description
}

National Cancer Institute

\section{Source}

National Cancer Institute. Unplanned Substance Use Description. NCI Thesaurus. Code C83434.

An indication or description of unexpected substance use data. 